contact, the chances of him surviving are so small as to make it foolish to try to pull him off. If, however, he has fallen clear, and any person wishes to risk his life in getting the victim into such a position as to enable first-aid attention to be given, then I should say that the best means of removing him would be with a long, dry pole or a long, dry rope, used in such a way as to keep the rescuer completely clear of the electrical equipment. Even this may be dangerous advice, because the pole or rope which would be suitable for $6.6 \mathrm{kV}$ would be totally unsuitable in length for 132 or $275 \mathrm{kV}$. It is on account of such considerations that $I$ think that any attempt at all at rescue by a person with insufficient knowledge of the electrical system concerned would be accompanied by very grave danger.

In the case of contact with a live electric rail, there are certain important differences. In Britain the railways use a direct current at a voltage of 600 -much lower than that envisaged above. Further, the current is automatically switched off if there is a short circuit. It is, in spite of newspaper reports, rather unusual for contact with a live rail to cause death. Lastly, a direct current has not the nasty trick that an alternating current has of making it impossible to let go.

(2) The treatment is the normal treatment for shock. Artificial respiration is required only when breathing is imperceptible. It should be carried on for at least two hours. It is sometimes urged that it should be continued until cooling of the body or rigor mortis indicates death.

(3) There is no danger of the victim remaining charged after breaking contact, for the simple reason that if he is receiving an electric shock some part of him must be in contact with earth. It is conceivable but highly improbable that he would be resting on two live conductors without touching earth, but immediately on falling from these conductors he would make sufficient contact with earth to make the possibility of anybody receiving a static shock from his body negligible.

(4) It is advisable in all cases of electric shock where consciousness has been lost to keep the patient recumbent for 24 hours. Particular care should be taken to examine the cardiac function. If the patient recovers consciousness the prognosis is good and no particular factors will influence it. It must be remembered, however, that severe cases of electric shock are accompanied by burns.

\section{Aluminium for Cooking}

Q.-Are there any dangers from using aluminium utensils for cooking? Are some people unduly sensitive to aluminium?

A.- There are no dangers from using aluminium utensils for cooking. This question has been investigated very thoroughly, and the results have established that of all the metals aluminium is the least toxic. It is less toxic than iron, and no cases of persons being sensitive to aluminium have been established. A report on this question was published by the British Non-Ferrous Metals Research Association (External Series, No. 162) in 1932.

\section{Treatment of Flushing}

Q.-What are the causes and treatment of flushing, as distinct from blushing? The patient, a man of 21 , is of good physique and has no other symptoms. The attacks of flushing of the face come on at any time, during a meal, at the pictures, when going for a walk, etc. The patient finds the condition most uncomfortable and sometimes embarrassing.

A.-Flushing is due to vasomotor instability and may occur in hyperthyroidism, hypogonadism, or without any obvious cause. The case in question appears to belong to the last category and treatment is likely to prove unsatisfactory. Overloading the stomach and alcohol should be avoided, and small doses of a sedative-e.g., phenobarbitone, $\frac{1}{t}$ to $\frac{1}{2}$ gr. (16 to $32 \mathrm{mg}$.) three times daily-together with a vasoconstricting drug such as ephedrine, $\frac{1}{2}$ to $1 \mathrm{gr}$. (32 to $65 \mathrm{mg}$.) three times daily, may be tried.
Inheritance of Deaf-mutism

Q.-A healthy young man wishes to marry a healthy girl of about the same age. She has six sisters, all healthy, but three brothers, all mute and deaf. What are the chances of these defects appearing in this couple's offspring? They cannot trace any similar defects in their other relatives.

A.-From the particulars given it must be assumed that the three brothers of the girl suffer from genetic deafmutism. This is due to a recessive gene, so there are two chances in three that she is a carrier. As the man has no history of deaf-mutism in his family, and assuming that he and the girl are not blood-relatives, the chance that he too is a carrier is remote. The risk that any of their children will be deaf-mutes is smaller than the risk that some serious congenital defect or other will occur in any random pregnancy. Thus the extra risk that this couple would be running may fairly be dismissed as negligible. It is far smaller than that taken whenever a Rhesus-negative woman marries a Rhesus-positive man, which happens in one marriage in every eight in this country. Nor need the girl feel any doubts about the possibility of passing on the gene to her children; in all probability we all carry at least one seriously harmful recessive gene, so if it was not this one it would be some other kind instead.

\section{Treatment of Cysticercosis}

Q.-Is there any useful treatment for cysticercosis, apart from dealing with symptoms as they come?

A.- -No, there is none of any proved value. Fortunately, the prognosis of cysticercosis is often favourable, even in cases in which epilepsy arises. Adequate symptomatic treatment and control of fits are therefore well worth while, and if continued for a period, which may need to be of several years' duration, the fits commonly become less frequent and cease permanently.

\section{NOTES AND COMMENTS}

Oestrogen in Mumps.-Dr. G. G. Jenner (Dunedin, New Zealand) writes: Your correspondent inquires about the use of hormones in mumps oophoritis ("Any Questions?" April 10, p. 888). R. Crosnier ${ }^{1}$ makes the following statement: "In case of mastitis, ovarian pain, or oophoritis in the woman or pubescent girl, rare incidents (rather than complications), use could be made of testosterone." He goes on to cast doubt as to whether sterility following such oophoritis is entirely due to the mumps. REFERENCE

1 Presse Médicale, 1952, 60, 1398.

\section{Corrections}

On p. 1506 of the July 26 issue of the Journal, "National Federation for Polio Research" should have read "National Fund for Polio Research."

We regret that among the signatures to the letter on "Medical Hypnosis" (July 3, p. 51) the name of Dr. W. Moodie was misspelt.

Refresher Course Books. - The first two volumes of collected articles from the Refresher Course for General Practitioners published in the Journal are now available. The first volume contains 55 articles and the second 60 . Each article has been revised by its author. Copies of both volumes may be obtained, price 25s. (postage 1s.) each, direct from the Publishing Manager, B.M.A. House, Tavistock Square, London, W.C.1, or from booksellers. The second book of "Any Questions?" is also available, price 7s. 6d. (postage 6d.).

All communications 'with regard to editorial business should be addressed to THE EDITOR, BRITISH MEDICAL JOURNAL, B.M.A. HOUSE, TAVISTOCK SQUARE, LONDON, W.C.1. TELEPHONE: EUSTON 4499. TELEGRAMS Aitlology, Westcent, London. ORIGINAL ARTICLES AND LETTERS Medical Journal alone unless the contrary be stated.

Medical Journal alone unless the contrary be stated. thors desiring REPRINTS should communicate with the Publishin Manager, B.M.A. House, Tavistock Square, W.C.1, on receipt of proofs. B.M.A. House, Tavistock Square, London, W.C.1 (hours 9 a.m. to 5 p.m.) B.M.A. House, Tavistock Square, London, W.C.1 (hours 9 a.m. to 5 p.m.) MEMBERS' SUBSCRIPTIONS should be sent to the SECRETARY of the Association. TELEPHONE: EUSTON 4499. TELEGRAMS: Medisecra, Westcent, London.

B.M.A. Scotrish OFFICE: 7, Drumsheugh Gardens, Edinburgh. 